\title{
NOTES ON COCCIDAE WITH DESCRIPTIONS OF NEW SPECTES.
}

\section{BY J. D. TINSLEY, NEW MEXICO EXPERIMENT STATION, MESILLA PARK, N. M.}

Exiococous Tinstex, Chil.

Adult of Length, 1.3 mu.; expanse of wings, 2.5 mm.; colour, head and abdomen purplish-gray; meso thorax light ochreus, sume specimens show a wide longitudinal strak on the abdomen. Legs and antemua concolorous with body. Intennae 10 jointed. Joint 2 is bottle shaped, proximal end smallest, $70 \mu$ long, practical!y identical with second joint of phonacocus solenopsis, Tins, except that $E$. Tinsleyi has a number of stont blunt spines interspersed with the bristles; joint 3 clindrical, considerably longer than any of the others $(130 \mu$ long) only differing from $P$. solcnopsis in having the stout blunt spincs; joint $t$ often shorter than 5 , but sometimes longer, $76-85 \mu ;$ joint $5,81-87 \mu$ long; joint 6 usually next, longer than 2, 68-78 $\mu$ long; Joint 7 shorter than 2. $68 \mu$ long; joint 10 usually next, $65 \mu$; next $8,56 \mu$ shortest $9,50 \mu$. Joint 10 is flask shaped, tapering distally. All the segments beat the siout blunt spines, interspersed with rather stout bristles. Formula $3,5,4,6,2,7,10,8,9$.

Legs rather slender; femur proximally, $180 \mu$ long, with some medium siced bristles; tibia quite slender, tapering very slightly proximally, $250 \mu$ long, quite bristly, with the stout blunt spines interspersed; tarsus bristy and with the stout blunt spines, $90 \mu$ long, hearing a pair of short stout digitules which are very slightly clilated at the end; claw rather slender, $20 \mu$ long.

The usual paix of long slender white caudal filaments. Male sac creanly white, about $2 \mathrm{~mm}$. Jong and $.75 \mathrm{~mm}$. wide, clliptical, inclining; to cylindrical.

Hab.-On roots and portions of stems lying on the ground, of Atriplex canescens. A. and M. College campus, Mesilla Park, N. M.; Aug. 1, 1898 ; coll. J. D. Tinsley.

Eriococcus Tinsleyi, Ckll.

․ Having recently studied this species somewhat in detail, I wish to add the following facts to Prof. Cockerell's description in Cinaman Extomologisr., Vol. XxX., No. 9, p. 247 . The antemia 
(Fig. 20) in this species ase quite variable both in regard to the relative length and actual size of the segments. I have observed the following $\begin{array}{llllll}4 & 3 & 7 & 2 & 5 & 6\end{array}$

formulae: $3 \begin{array}{llllll} & 4 & 2 & 7 & 6 & 5\end{array}$. While in many cases the tarsus is longer than $\begin{array}{llllll}4 & 3 & 2 & 7 & 6 & 5\end{array}$

the tibia (Ckll., loc. cit.), yet they are often subequal. The full-grown roung femiles appeat much more spiny than the old females.

Some time since I received specimens on Malvastrum coccineum,

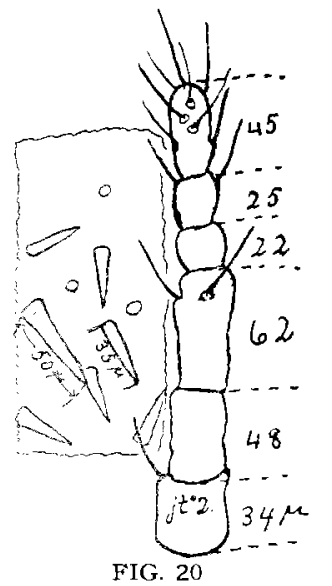
collected by $\mathrm{Mr}$. E. Bethel, at Denver, Colo., wbich I at the time thought to be a distinct species, and from those specimens prepared the accompanying figure. I now consider them to be this species.

Prof. Cockerell has, in Aug., 1898, collected specimens on the leaves of Atriplex canescens, growing on the campus of the $A$. and M. College of N. M., which I also refer to this species.

The Colorado specimens are fairly constant in their antennal formulae of 432756 .

The specimens on the leaves of Atriplex are 347256 (34) 7256 $3(47) 256$ $34(72) 56$

Their legs and antennae are stouter than in the type form, and they have more hairs between the bases of the antennac and legs.

DACTylopius KingI, Ckll., var. Neo-Mexicana, n. var.

During the past summer I collected this insect on the roots of Gutierrezia sarothrae in the Organ Mts., N. M., at an altitude of about 5,000 fect. They were, in all cases, attended by ants.

Adult $q$. Length, $2 \mathrm{~mm}$.; width about $1 \mathrm{~mm}$. Shape, ellipsoidal, rather plump. Colour yellowish. Nearly naked; no lateral or caudal filaments; dorsum sparsely mealy. The antennac are 8-jointed, and with the formula of Kingii, 81235764 , the fourth joint, while shortest, is relatively longer than it usually is in Kingii. Hairs on the segments about the same as in Kingii, perhaps a little smaller. The whole antenna is a little smaller than is usual in Kingii. Legs are rather smaller than in Kingii ; fenur 130 $\mu$ long; tibia, $140 \mu$ long; tarsus, $75 \mu$ long; 
claw, $25 \mu$ long. Hairs and digitules nearly as in Kingii. The most marked difference is in the ovisac. Kingii secretes a loose, fluffy, shapeless ovisac, while this var. secretes a compact, elliptical ovisac, very little larger than the female, in which the female lies partially embedded. The ovisac resembles that of an eriococcus very much.

Pilfanacocus solenopsis, Tinsley.

Adult $\hat{o}$. Length, 1 mm.

Colour white, head tinged with gray, eyes red, mesothorax yellowish, legs light rellowish brown. Antennae 10-jointed; joint 1 short and stout, $35 \mu$; joint 2 bottle shaped, proximal end smallest, $70 \mu$ long; joint 3 is considerably longer than any of the others, being $120 \mu$ long; joint 5 next, being $90 \mu ; 6$ next, $85 \mu$; the remaining joints are variable in relative length. Formulae of the antennae of one

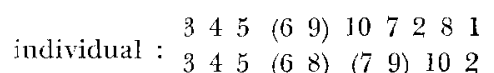

All the segments are quite bristly. Legs rather slender. Fenur $250 \mu$ long, bearing a few bristles; tibia $265 \mu$ long, bearing numerous stout bristles; tarsus $95 \mu$ long, bearing numerous stout bristles; claw $31 \mu$ long, rather slender. Tarsal digitules long and slender; claw without digitules. The usual caudal filaments.

Hab.-On roots of Atriplex cancscens; Aug. 4, 1898; coll. J. D. Tinsley.

Dactylopius Azalear, n. sp.

Adult $q$. About $3 \mathrm{~mm}$. long, about $2 \mathrm{~mm}$. wide.

Flattened ellipsoidal, rather pointed at the ends. Colour of dried specimen, purplish-gray secretion, white, granular, practically hiding the true colour of the body. Lateral filaments very short on the thorax, increasing in length toward the anal extremity. Caudal filaments not conspicuously longer than those of posterior segments of the abdomen. The lateral and caudal filaments are just easily seen with the naked eye. Epidermis with numerous spinnerets. Dorsum with scattered, rather large, hairs. Ventrally the hairs are quite large and rather numerous, especially on the posterior segments. Largest hairs on posterior segments are $60 \mu$ long. Sides with rows of spinneret spine areas.

Antennae colour reddish, 8-jointed; medium size, all the joints have quite long hairs. The joints are rather variable in their relative lengths; 
1 and 2 are ofion subequal, although in many cases 2 is appreciably longer, and 3 may be longer than $1 ; 5$ is most musually longer than $7 ; 4$ and 6 are shortest, sonetimes one and sometimes the other. Two of the most common formulae are $\delta(12) 35716$ a $n$ d 82315764 . (See figure 21.) Lcgs reddish, modium size. Femur, $215 \mu$ long, $85 \mu$ wide, with long, mather slender hairs.

Iibia $215 \mu$ long, with long, rather slender haits; tarsus $112 \mu$ long; claw $33 \mu$ long: digitules of tarsus 10 a long, knobied ; digimics of claw long, slencler, knobbed.

Anal lobes bearing one large long hair (250 $\mu$ long), and one

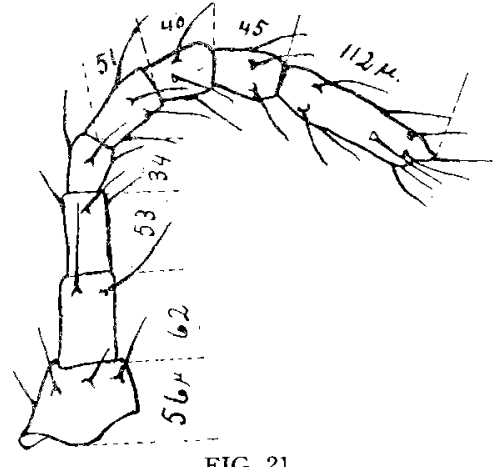
FIG. 21. smaller hair. The usual group of spinnerets and spines. The spines quite stout.

Inal ring with the usual o hatrs. which are quite large (110 $\mu$ long).

Boiled in potash the insects turn a very dark bluish green, almost black; if the are now veated with acid they turn red. The colouring mater contancd in this inscet has been found in but fer other Coccids; mos Coccids turning a rod, of some shade, when treated with potash.

Oxisac loose and fluffr, white. not covering the lemale, but containing the eggs, which are purplish.

Hab.-On Azalca in Japanese nursery, San José, Cal. Collected by Mr. Fdward M. Ehrhorn : Sept., 1898.

Remarks.-This species is very closcly allied to D. pandani, Ckll., especially in the characters of the antennae, anal lobes and ring, and the hairs on the epidermis. It differs, however, in colour, secretion on margin, and colour in potash. Being found in a Japanese nursery, it is almost impossible to say from rhence it came, but it may possibly be Japanese. 